
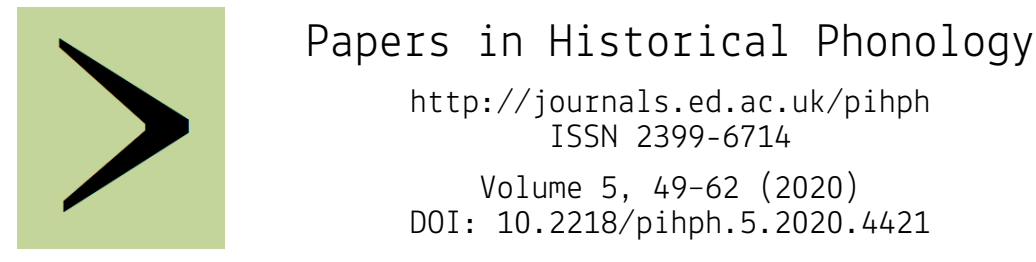

DOI : 10.2218/pihph.5.2020.4421

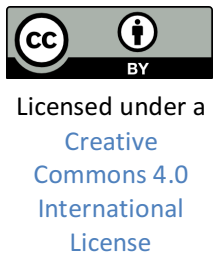

\title{
On 'affective' exceptions to sound change: an example from the Mojeño (Arawakan) kinship terminology system
}

\author{
FERnANDo 0. DE CARVALHO \\ Federal University of Amapá
}

\begin{abstract}
This paper discusses a postulated non-sound change-based development derived from the detection of an exception to a regular segmental correspondence and shows how this proposal receives independent support from internal etymologization within the domain of kinship terms. The affricate in the Proto-Mojeño etymon *-ótse 'grandmother' is hypothesized to derive from affective strengthening of a fricative *s, thus modifying the expected reflex *óse via affective or phonosymbolic affrication. The fact that the predicted fricative reflex is found when *óse 'grandmother' occurs as a member of a compound for 'mother-in-law', a meaning not subject to affective modification, offers striking support for the hypothesis. The paper illustrates how internally structured lexical fields - where relations of partial (internal) cognation exist - such as kinship terminology systems, provide an interesting testing ground for claims on affective, non-lautgesetzlich formal modifications, given the fact that etymologically related forms belong to domains (such as 'blood relative' versus 'affine relative') that differ in crucial ways as far as the affective dispositions and attitudes of speakers are concerned.
\end{abstract}

\section{Introduction}

The goal of this short paper is to make accessible to a wider audience interested in diachronic phonology and the nature of sound change a finding that could, otherwise, remain buried within some specialized publication on the indigenous languages of South America. Because the relevant pattern consists of a striking independent confirmation of a hypothesis designed to account for an apparent exception in a regular segmental correspondence (that is, an apparent exception to sound change), this is bound to attract the interest of historical linguists more generally, and to enlarge the genetic, areal and typological scope of data often used in discussions of these matters. 
In a study devoted to the historical phonology of three of the southernmost members of the Arawakan language family - Mojeño, Paunaka and Terena - Carvalho (2018) claims that some development other than regular, phonetically-based sound change is responsible for the occurrence of the affricate ${ }^{*} t s$ in the Proto-Mojeño (henceforth, PM) etymon *-ótse 'grandmother'. A fricative is the expected outcome (yielding *-óse 'grandmother'), based on regular correspondences among cognate elements of the three languages. The correspondences in question, along with exemplar cognate sets, are indicated in (1), after Carvalho (2018).

(1) Correpondences for PM, Paunaka and Terena

(a) $\mathrm{PM}^{*} s$ : Paunaka $s$ : Terena $s$

$$
\begin{array}{ll}
\text { *eseno : esenu : sêno } & \text { 'woman' } \\
\text { *-iso- : -su : -íso } & \text { 'weed out' } \\
\text { *-esane-ti : -asane-ti : isáne } & \text { 'garden' }
\end{array}
$$

(b) PM *ts : Paunaka $s$ : Terena $s$

$$
\begin{array}{ll}
\text { *motsi-pa : musi-pa } & \text { 'eyelash' } \\
\text { *titsi }: \text { tisi } & \text { 'red' }
\end{array}
$$

(c) PM *t: Paunaka $s:$ Terena $s$

$$
\text { *itfini : isini : sîni 'jaguar' }
$$

The main correspondence appears in (1a), where the PM fricative ${ }^{*} s$ is matched by identical fricative reflexes in Paunaka and Terena. This correspondence is attested in the context of vowels other than $* i$, while those in (1b) and (1c), distinguished from (1a) only because of the PM reflexes, occur preceding $* i$ (the diverging reflexes $\mathrm{PM} * t s$ and $\mathrm{PM} * t$ are conditioned by additional prosodic factors). These three correspondences are analyzed in Carvalho (2018) as reflexes of *ts at the level of the shared common ancestor of PM, Paunaka and Terena, tentatively called 'ProtoAchane'. The reader is referred to Carvalho (2018) for the full argumentation. The relevant point here is that a single form has been identified by the author as an exception, PM *-ótse 'grandmother', since, in this form, $\mathrm{PM} * t s$ is found preceding PM ${ }^{*} e$, whereas $\mathrm{PM} * s$ would be expected given the main correspondence in (1a).

\section{The Mojeño language}

Mojeño (also Moxeño, Moxo) belongs to the 'Bolivia-Paraná' subgroup of the Arawakan family (Payne 1991, Carvalho \& Rose 2018) and is known to us in five lects: Ignaciano, Trinitario, Javeriano, Loretano and 
Old Mojeño (henceforth, OM), the latter documented in the late 17th century in a number of Jesuit missions established in the region. Given that hardly any documentation exists on lects other than Ignaciano, Trinitario and $\mathrm{OM}$, these have served as the basis for comparative investigations of this dialect cluster and this practice will be followed here. As noted by Carvalho \& Rose (2018), there is no reason to assume that the OM documented in the 17th century by Pedro Marbán, and less so by Father Iráisos, is the direct ancestor of any of the existing varieties of the language. The territory traditionally occupied by Mojeño speakers consists of a vast flood plains region in the Bolivian Amazon, between the Beni and Guaporé rivers, and centering around the Mamoré river (Rose 2015).

Carvalho \& Rose (2018) reconstruct the phonological inventory and 191 etyma for PM. The consonantal and vocalic phonological inventories are presented in tables 1 and 2.

\begin{tabular}{c|c|c|c|c|c} 
& Labial & Alveolar & Palatal & Velar & Glottal \\
\hline \hline Oral Stops & ${ }^{*} p$ & ${ }^{*} t$ & & ${ }^{*} k$ & ${ }^{*} ?$ \\
\hline Affricates & & ${ }^{*} t_{s}$ & ${ }^{*} t$ & & \\
\hline Fricatives & & ${ }^{*} s$ & & & ${ }^{*} h$ \\
\hline Nasal Stops & ${ }^{*} m$ & ${ }^{*} n$ & ${ }^{*} n$ & & \\
\hline Rhotic & & ${ }^{*} r$ & & & \\
\hline Approximant & ${ }^{*} w$ & & ${ }^{*} j$ & &
\end{tabular}

Table 1. Proto-Mojeño consonants

The Trinitario dialect has innovated a palatal fricative $c$ and a palatal stop $c$ via phonologization (allophonic shift and loss of conditioning context), while Ignaciano innovated a (distributionally restricted) alveo-palatal fricative $\int$ via phonosymbolic processes.

\begin{tabular}{c||c|c|c} 
& Non-Back & Back Unrounded & Back Rounded \\
\hline \hline High & ${ }^{*} i$ & & ${ }^{*} u$ \\
\hline Mid & ${ }^{*} e$ & & ${ }^{*} o$ \\
\hline Low & & ${ }^{*} a$ &
\end{tabular}

Table 2. Proto-Mojeño vowels

Trinitario additionally shows a central, complex monophthong $\widehat{\partial e}$ and has developed contrastive vowel length from compensatory lengthening after the dissolution of certain consonant clusters created by 
widespread process of vowel syncope. Finally, Ignaciano has a single back rounded vowel $u$, since PM ${ }^{*} a$ and ${ }^{*} o$ merged unconditionally as $a$ in this variety (the reader is referred to Carvalho \& Rose 2018 for details).

\section{3 'Mother-in-law' = 'the grandmother of my children', an etymo- logical association}

As noted in the Introduction, PM *-ótse 'grandmother' is exceptional, in that a medial fricative ${ }^{*} s$ is expected, instead of the medial affricate (based on regular correspondences with other, closely related sister languages). The fact that PM *-ótse 'grandmother' has an internal (partial) cognate in the derivative formation PM *imose <*-ímV-ose 'mother-in-law', where the expected $s$, rather than $t$, appears, provides a striking confirmation for the proposal of 'affective phonosymbolism' as the explanation for the unexpected affricate in PM *-ótse 'grandmother'. I will first discuss the existence of this etymological relation, and then come back to a consideration of how it furnishes evidence for the affective interference with the regular development in question.

As first suggested by Taylor (1961) on the basis of scant and limited data, Arawakan languages (and, arguably, Cariban languages as well) show a particularly interesting pattern of etymological associations between kinship terms denoting, on the one hand, blood relatives of the grandparental generation ('grandfather' and 'grandmother') and, on the other hand, affine relatives of the parental generation ('father-in-law' and 'mother-in-law'). This is exemplified below (table 3) on the basis of modern data from a geographically representative sample of Arawakan languages (sources: Rowan 2008, 86, 116 for Paresi; WLP 2000, 35, 91 for Wapixana; Parker 1995, 25, 66 for Iñapari; and, for Terena: Ekdahl \& Butler 1979, 113-114 and the author's own field data).

\begin{tabular}{|c|c|c|c|c|}
\hline & Grandfather & Father-in-law & Grandmother & Mother-in-law \\
\hline Proto-Mojeño & *-ótfuko & *-ímotguko & ${ }^{*}$-ótse & *-ímose \\
\hline Paunaka & -utfiku & -mutfiku & -use & -muse \\
\hline Terena & $-\hat{o} / u$ & -imófuko & -ôse & -imóse \\
\hline Wapixana & -dokozi & -imadokozi & -ïzo & -imaižo \\
\hline Paresi & -atyoko & -imatyoko & -asero & -imasero \\
\hline Iñapari & -atuhiri & -imatuhitiri & -ahiro & -imahitiro \\
\hline
\end{tabular}

Table 3. Terms for blood and affine relatives in diverse Arawakan languages

The relevant pattern in table 3 is that, for every language listed, the affine term (in the shaded columns) seems related to the form for 
grandparent of the same sex by addition of a word-initial formative of a form close to *(i)m-. This tentatively identified formative agrees with Taylor's (1961) original proposal, based on evidence from Island Carib, that a form close to -im "should be added to the list of Arawakan forms referring to child" (Taylor 1961, 78). That is, the forms for affinal relatives in table 3 would derive from compounds meaning 'grandmother of child' (= 'mother-in-law') and 'grandfather of child' (= 'fatherin-law'), which consist of descriptive kinship terms whose semantic rationale is rather easy to grasp: One's parental affines (the parents of one's spouse) become, once the first children of a married couple are born, the grandparents of one's children. As our focus here lies on Proto-Mojeño, I will concentrate on these etymological relations as they can be recovered from PM reconstructions, indicated in the uppermost line of data in table 3 . The following discussion is necessary, since Taylor's (1961) original proposals on the nature of these compounds, and, in particular, on how general among Arawakan languages a form similar *-im 'child' is, was very tentative and limited in scope.

Based on the cognates -ímase 'mother-in-law', -ímatuka 'father-inlaw' (Ignaciano; see Ott \& Ott 1983, 627), -imse 'mother-in-law', -imtko 'father-in-law' (Trinitario; see Gill 1993, 38) and OM <nimachucò> 'father-in-law' and <nimosè> 'mother-in-law' (Marbán 1701, 341), where $n$ - in the OM forms is the first person singular possessive prefix $n(u)$ - (see Carvalho \& Rose 2018), the PM forms for 'father-in-law' and 'mother-in-law' are easily reconstructed as *ímotfuko and *-ímose, respectively. The reader can check for themself the consistency of the proposed etyma with the regular segmental correspondences presented in Carvalho \& Rose (2018). ${ }^{1}$

\footnotetext{
1 Strictly speaking, in agreement with the known correspondences between the Mojeño lects employed for comparison, PM *ímotfuko 'father-in-law' would have to be reconstructed as ${ }^{*}$-imVtfuko, with an unspecified medial vowel, since the crucial evidence from Trinitario is, in this case, lacking due to the effects of diachronic syncope in this language (see Carvalho \& Rose 2018 for details). See, however, that a back rounded vowel ${ }^{*} o$ is justified also based on the sparsely documented Loretano variety of Mojeño, where the form <nimúchuko> 'suegro' (Becerra Casanovas 1980, 22 ) is attested, providing an independent witness for the back rounded character of this medial vowel.
} 


\begin{tabular}{c||c|c} 
& 'father-in-law' & 'mother-in-law' \\
\hline \hline Proto-Mojeño & *-ímotfuko & *-ímose \\
\hline Old Mojeño & <nimachucò> & $<$ nimosè> \\
Ignaciano & -ímatfuka & -ímase \\
Trinitario & -imtgko & imse
\end{tabular}

Table 4. Etymologies for PM 'father-in-law' and 'mother-in-law'

As proposed, PM *-ímotfuko 'father-in-law' and PM *-ímose 'motherin-law' can be etymologized as derivatives (compounds) whose second elements are, respectively, the etyma *ótfuko 'grandfather' and *-ótse 'grandmother', and whose first element is the PM root*-ímV-, whose meaning was, I propose, 'shoot (n.), sprout (n.); first-born child'. Table 5 below presents the etymologies for PM *-ótse 'grandmother' and *-ótfuko 'grandfather', as reconstructed in Carvalho \& Rose (2018).

\begin{tabular}{c||c|c} 
& 'grandfather' & 'grandmother' \\
\hline \hline Proto-Mojeño & *-ótfuko & *-ótse \\
\hline Old Mojeño & $<$ nu-achuco $>$ <nu-oze> \\
Ignaciano & -atfuka & -atse \\
Trinitario & -otfko & -otse
\end{tabular}

Table 5. Proto-Mojeño etymologies for 'grandfather' and 'grandmother'

Of relevance to the coming discussion, note that $\mathrm{PM}^{*}$-ts- in the term for 'grandmother' is supported by a regular identity correspondence between $t s$ in all three lects or varieties (on Old Mojeño's $\langle z\rangle=t s$, and the relevant identity correspondence, see Carvalho \& Rose 2018).

The reflexes of PM *-ímV- 'shoot (n.), sprout (n.); first-born child', the first, leftmost element in the compounds for affines of the parental generation, are given in table 6 below.

PM *-imV

'first-born child, sprout (n.), shoot (n.)'

\begin{tabular}{c||c|c||c}
\hline \hline & 'first-born child' & 'sprout, shoot' & Source \\
\hline Old Mojeño & $<n$-imo-ru> & $<$ ta-ima-ru> & Marbán $(1701,315,504)$ \\
Ignaciano & (-áratfitfa) & -íma-ru & Ott \& Ott $(1983,78,224)$ \\
Trinitario & ima-ruupe & -íma-ru & Gill $(1993,20,35)$
\end{tabular}

Table 6. Proto-Mojeño *-im $V$ and supporting set of reflexes 
Given the proposed reconstruction, we can see that PM *im $V$ was subject to semantic narrowing in Ignaciano, where it means only 'sprout, shoot' (being replaced by -áratfita in the meaning 'first-born child'; 'primer hijo o hija', literally 'new child', see Ott \& Ott 1983, 78), while the two meanings were morphologically distinguished in Trinitario, with the derivative imaruupe now standing for the meaning 'first-born child'. The case of Old Mojeño is more complex and raises some questions.

Addressing first the formal issues with this proposed etymology, I reconstruct ${ }^{*}$-ím $V$-, a simple CVC root, since the formative -ru (attested in all reflexes) can be excised as an independent morpheme: the nominal suffix *-ru (Ott \& Ott 1983, 23; Rose 2015, 85), described as a 'past participle' marker by Marbán (1701, 43-44). The provisional reconstruction of an unspecified final vowel reflects uncertainty concerning the interpretation of the coexistence, in $\mathrm{OM}$, of <taimaru> 'los brotes' ('sprouts (n.), shoots (n.)'; Marbán 1701, 504) and <nimorú> 'Primogenito' ('first-born child'; Marbán 1701, 315). ${ }^{2}$ As noted in Carvalho \& Rose (2018), the main correspondence for $\mathrm{PM}{ }^{*} o$ is Ignaciano $a$ : Trinitario $o$ : OM $o$ (while $\mathrm{PM}^{*} a$ is supported by an identity correspondence in all three varieties and Ignaciano has merged PM ${ }^{*} o,{ }^{*} a>a$; see Carvalho \& Rose 2018 for details). Exceptional and restricted occurrences of OM $a$ (instead of $o$ ) matching Trinitario $o$ and Ignaciano $a$ have been attributed to dialectal borrowing in the context of the 17th century missions, when speakers of different varieties were brought under the tutelage of the Jesuit missionaries. The case in hand is, however, more problematic, since Trinitario also shows $a$ and because $\mathrm{OM}$ alone has two semantically close forms differing only in their vocalism: <nimorú> 'first-born child', <taimaru> 'sprout, shoot'. Given these complexities, I provisionally reconstruct a vowel of unspecified quality in PM *-imV 'first born child, sprout (n.), shoot (n.)'. It is possible that the two $\mathrm{OM}$ forms are doublets reflecting variants of the PM form *-imV, separate variants becoming specialized for each of the meanings. OM materials display many cases of these alternative forms differing only in relation to the $o \sim a$ vocalism. In some such cases 'free variation' seems to be at play, as in the nouns <yoboti> 'cuña de fierro, hacha' ('axe'), with two variants of the possessive form: <nuyobo> and <nuyabo> (Marbán 1701, 647), or <Ecari> 'Sepultura' ('grave'), noted explicitly by Marbán $(1701,649)$ as having a variant $<$ Ecori $>$. In other cases still, one finds paradigmatically-related yet

2 In the OM forms, $n$ - is the $1 \mathrm{SG}$ possessor prefix, $t a$ - is the 2SG non-human prefix (see Rose 2015 for details). 
distinct word-forms displaying similar formal relations, as in $<$ Echabicò> 'Hombre de edad, y mayor que otro' ('Elder male'), but possessive <Nechobi> (Marbán 1701, 469). For the time being, then, until these Mojeño-internal factors involving restricted alternations and dialectal borrowing are sorted out, I will keep an unspecified vowel in the etymon *-imV- 'first-born child, sprout (n.), shoot (n.)'.

Addressing now the semantic issues with the proposed equations, note that the polysemic composition of the meanings 'shoot (n.), sprout (n.)' and 'first-born child' in the PM etymon *-imV-is, despite appearances of the contrary, unproblematic. In fact, a clear parallel is found in the Island Carib cognate mentioned above in relation to Taylor's original proposals. Taylor $(1961,78)$ observes that Raymond Breton's glosses for Island Carib -im include 'son', 'seed', 'fruit', 'egg'. Earlier, Taylor (1957, 286) cited Island Carib -imetámulu '(man's) father-in-law' and -iménuti '(man's) mother-in-law' as transparent compounds whose first element was a root -im- 'fruit, seed, son, egg', the precise meaning depending on the context. While 'child' and 'seed' seem to be associated in metaphorical extensions in other domains, in particular in the widespread terms for the eye's pupil ('child of the eye', 'seed of the eye'; see Brown \& Witkowski 1981), the base of comparison for the semantic association seems to be different in the two cases. In the case of the eye's pupil both 'child' and 'seed' seem to share a core sense of 'smallness' (Brown \& Witkowski 1981, 601); in the colexification of notions such as 'child', 'seed', 'egg' and 'sprout' the base for comparison seems to relate to a notion of 'embryonic stage', or the like. More importantly, though, the synchronic polysemy involving these notions in Island Carib shows that postulating a single PM etymon relating the meanings 'first-born child' and 'sprout (n.), shoot (n.)' or 'seed' creates no unsurmountable challenges for the acceptance of the relevant etymology.

Finally, note that, in addition to Island Carib -im 'seed, fruit, egg, son', another external cognate supporting PM *-imV is found in Apurinã, a member of the Purus branch of the Arawakan family, where the independent (non-compound) root $\varnothing$-imi 'his son' (Freitas 2017, 406) is attested.

Summing up then, the PM kinship terms for affines of the parental generation are here proposed to originate in PM compounds whose first element is a root *-imV meaning 'first-born child', but also 'sprout (n.), shoot (n.)', and whose second element are the forms for 'grandfather' and 'grandmother'. The etymological relations between these terms are depicted in (2). 
(2) Derivation of PM terms for parental affines

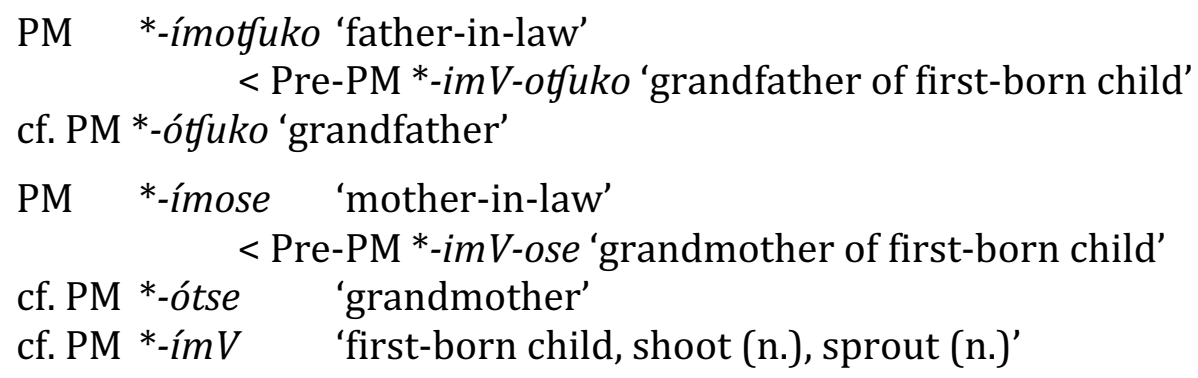

The main formal observation here, to be addressed in detail in the next section, is a PM-internal correspondence between and affricate ${ }^{*} t s$ in the root *ótse 'grandmother' and the fricative ${ }^{*} s$ in the same formative, when used as a compound member in *-imV-ose 'mother-inlaw' (lit. 'grandmother of first-born child').

On the structure of the postulated PM compounds, note that the pattern in *ímV-otfuko 'father-in-law' and *ímV-ose 'mother-in-law', where *otfuko and *-ose are, respectively, the semantic heads of the compounds, is entirely in agreement with the rules for compound formation in the extant Mojeño dialects. Thus, in the Trinitario dialect, for instance, from nouns such as waka 'cow', -etfe 'flesh', himo 'fish' and teruhi 'food', one can form the nominal compounds wakaetfe 'cow meat, beef' and himotfeehi 'fish food' (Ibáñez Noza et al. 2009, 55-56), where the head of the compound is clearly the rightmost noun. Similar formations are attested for Old Mojeño (e.g. <Achaneeché> 'human flesh', with <-eche> 'flesh, meat' as the rightmost, head noun; see Marbán 1701, 172) and, in fact, is consistent with nominal compound patterns in other languages of the family, such as Paresi (Brandão 2014, 177), Apurinã (Facundes 2000, 211) and Garifuna (Taylor 1956, 42).

\subsection{Identifying an affective dimension in exceptions to regularity}

The discussion in the preceding section was necessary to justify the claim that PM *-ótse 'grandmother' has an internal cognate preserved within a compound of a rather opaque structure. A notable aspect of this cognation relation is the fact that an affricate ${ }^{*} t s$ in the form for 'grandmother' matches ${ }^{*} s$ in the compound member for 'mother-inlaw'. This internal formal mismatch can be related to the comparative pattern (see section 1) whereby PM *ts in 'grandmother' is unexpected or unexplained. This can be made sense of by postulating a non-sound change-based development that 'hardened' the PM fricative ${ }^{*} s$ in the form for 'grandmother', while leaving it unaffected as a compound member in the form for 'mother-in-law'. I will now flesh out this proposal in detail. 
As is well-known, affective or expressive symbolism is a common cause of disruptions in regular correspondences, such as the case at hand (see for instance the discussion in Campbell 1996, 73-77). ${ }^{3}$ The account proposed by Carvalho (2018), and mentioned in the section 1 , is depicted in (3) below with the parallel developments of the two relevant Pre-PM etyma in PM.

(3) Phonosymbolic 'affective' hardening in Mojeño

$\begin{array}{llll}\text { Pre-PM } & & \text { PM } & \\ \text { *-óse } & \text { *-ótse } & \text { 'grandmother' } \\ \text { *-ímV-ose } & > & \text { *-ímose } & \text { 'mother-in-law' }\end{array}$

In (3), the double-arrow '>>' stands for a development which cannot be explained in terms of sound change alone. ${ }^{4}$ That is, at a PrePM level, the expected PM reflex of the Proto-Achane affricate ${ }^{*} t s$ was in fact *s; at a later point, however, it was 'hardened' to *ts based on a nonlautgesetzlich formal modification, one that, in agreement with its character, targeted the Pre-PM form *-óse 'grandmother' specifically.

The proposed development ${ }^{*} s>{ }^{*} t s$ is paralleled by ample typological evidence from similar processes (either synchronic or diachronic) involving the symbolic use of sound expression in the semantic domain of 'endearment', 'diminutives' and 'affection' (see e.g. Nichols 1971, 828-829 for a classic discussion). Typological generalizations on the phonetic segments related by these expressive modifications are also consistent with the change proposed here for Pre-PM ${ }^{*} s$, given the nearly exclusive limitation of expressive palatalization to target coronal segments, in particular, sibilant fricatives, and due to this process' strong preference for affricates as its output (see Kochetov \& Alderete 2011, 350-351). Of crucial relevance is, however, the semantic (and, one could add, 'attitudinal') difference between the two Pre-PM etyma in (3): assuming that such expressive developments can often be traced to baby talk, that is, conventionalized speech patterns directed at children (Kochetov \& Alderete 2011), or, in a similar vein, to "evocations of the nurturant-baby relation" (Ferguson $1964,111)$, it is far from surprising that ${ }^{*} s>{ }^{*} t s$ has taken place in the term for 'grandmother', but not in the derivative formation meaning

\footnotetext{
3 'Affective' or 'phonosymbolic' modifications are in this paper understood in the sense of Campbell $(1996,73)$, that is, as "(...) the deployment of certain phonetic aspects of a language to reflect or symbolize affectations, heightened expressive value, or the speaker's attitude".

4 Though certainly not standard, use of this notation is common, in particular in IndoEuropean historical linguistics (see e.g. Nikolaev 2009).
} 
'mother-in-law'. Terms for affines are, to the contrary, often the target of taboos, having their meanings and forms constrained by strict respect relations in many societies - and, quite probably, for obvious reasons, do not figure among the most salient elements in infantdirected speech, or in adult-infant interactions in general. ${ }^{5}$ Finally, as discussed in Carvalho \& Rose (2018), such expressive phonetic effects are attested elsewhere in the historical phonology of the Ignaciano variety of Mojeño, and closely related languages also display similar patterns, as in Terena -ôse 'grandmother' (cf. ôte/otête 'granny') and -ôfu 'grandfather' (cf. ôtu 'grandpa'). We can conclude, in agreement with Carvalho's (2018) hypothesis, that while the affine term PM *-imose 'mother-in-law' (< Pre-PM *-imV-ose) retains the expected reflex of 'Proto-Achane' *ts in Mojeño, Pre-PM *-óse 'grandmother' was modified by a phonosymbolic development that typically targets affective vocabulary

\section{Conclusion}

I hope to have added an interesting exemplification from a rather understudied, 'exotic' language group, illustrating a central feature of the application of the comparative method, to this day the sine qua non of historical linguistics. The explanation of an apparent exception to regular segmental correspondences as involving phonosymbolic or affective formal modifications was vindicated by the careful etymological exploration within a highly structured lexical domain, that of kinship terms, thus adding to the mass of existing evidence that the comparative method's foundation on the existence of regular, phonetically-conditioned sound change (or sound change, simply) is not a vacuous assumption that can be salvaged at will by invoking ad hoc, auxiliary hypotheses like non-lautgesetzlich developments, analogy or dialectal borrowing. Quite to the contrary, it illustrates in a particular forceful way the productive character of the Neogrammarian definitional proposal that regular sound change exists: It is only on the basis of this assumption that other, non-sound change-based modifications can be identified, as was the case for the Pre-PM fricative strengthening.

\footnotetext{
${ }^{5}$ Affinal relatives are particularly focused by both linguistic and non-linguistic respect relations and avoidance behaviors (see e.g. Murdock 1971, Flemming 2014). In fact, in certain Amazonian groups, even uttering the names of affines is forbidden (Aikhenvald 2012, 362), and this widespread naming taboo could lie behind the emergence of descriptive kinship terms. In some cases, even non-descriptive kinship terms can be avoided in favor of more 'respectful' descriptive terms (such as 'offspring's father' instead of 'husband'; see Basso 2007 for the case of the Kalapalo).
} 


\section{Comments invited}

PiHPh relies on post-publication review of the papers that it publishes. If you have any comments on this piece, please add them to its comments site. You are encouraged to consult this site after reading the paper, as there may be comments from other readers there, and replies from the author. This paper's site is here:

https://doi.org/10.2218/pihph.5.2020.4421

\section{Author contact details}

Fernando O. de Carvalho

Federal University of Amapá (UNIFAP)

Rodovia Juscelino Kubitschek, km-02

Macapá, Amapá state (Postal code: 68.903-419)

Brazil

fernaoorphao@gmail.com

\section{References}

Aikhenvald, Alexandra. 2012. The Languages of the Amazon. Oxford: Oxford University Press.

Basso, Ellen. 2007. The Kalapalo affinal civility register. Journal of Linguistic Anthropology 17(2). 161-183.

Becerra Casanovas, Rogers. 1980. De Ayer y de Hoy: Diccionario del Idioma Mojeño a través del Tiempo. Estudio Comparativo Sobre su Evolución. La Paz: PROINSA.

Brandão, Ana Paula. 2014. A reference grammar of Paresi-Haliti (Arawak). Doctoral Dissertation, University of Texas at Austin.

Breton, Raymond. 1999 [1665]. Dictionaire Caraïbe-Français. Paris: Éditions Karthala.

Brown, Cecil H. and Stanley Witkowski. 1981. Figurative language in a universalist perspective. American Ethnologist 8(3). 596-615.

Campbell, Lyle. 1996. On sound change and challenges to regularity. In: Mark Durie and Malcolm Ross (eds.) The Comparative Method Reviewed: Regularity and Irregularity in Language Change, 72-89. New York and Oxford: Oxford University Press.

Carvalho, Fernando 0. de. 2018. The historical phonology of Paunaka (Arawakan). Boletim do Museu Paraense Emílio Goeldi 13(2). 405428. 
Carvalho, Fernando 0. and Françoise Rose. 2018. Comparative Reconstruction of Proto-Mojeño and the Phonological Diversification of Mojeño Dialects. LIAMES (Línguas Indígenas Americanas) 18(1). 7-48.

Ekdahl, Elizabeth and Nancy Butler. 1979. Aprenda Terêna. Summer Institute of Linguistics.

Facundes, Sidney. 2000. The Language of the Apurinã (Arawak) People of Brazil. Doctoral Dissertation, SUNY at Buffalo.

Ferguson, Charles A. 1964. Baby talk in six languages. American Anthropologist 66(6). 101-114.

Flemming, Luke. 2014. Australian exceptionalism in the typology of affinal avoidance registers. Anthropological Linguistics 56(2). 115158.

Freitas, Marília. 2017. A posse em Apurinã: Descrição de construções atributivas e predicativas em comparação com outras línguas Aruák. Doctoral dissertation, Universidade Federal do Pará (UFPA), Belém, Brazil.

Gill, Wayne. 1993. Diccionario Trinitario-Castellano. San Lorenzo de Mojos: Misión Nuevas Tribus.

Ibáñez Noza, Eulogio, Basilio Nojune, Claudio Jare, Adalberto Pedraza, Bartola Jare and Liverato Noza. 2009. Gramática Mojeña Trinitaria, Tomo II. Centro Social y Comunitario Ipeno Imutu. Trinidad, Beni, Bolivia.

Kochetov, Alexei and John Alderete. 2011. Patterns and Scales of Expressive Palatalization: Experimental Evidence from Japanese. Canadian Journal of Linguistics 56(3). 345-376.

Marbán, Pedro. 1701. Arte de la Lengua Moxa, con su Vocabulario, y Cathecismo. Lima: Imprenta Real de Joseph de Contreras.

Murdock, George Peter. 1971. Cross-sex patterns of kin behavior. Ethnology 10(3). 359-368.

Nichols, J. 1971. Diminutive Consonant Symbolism in Western North America. Language 47(4). 826-848.

Nikolaev, Alexander. 2009. The Germanic word for 'sword' and delocatival derivation in Proto-Indo-European. Journal of IndoEuropean Studies 37(3/4). 462-488.

Ott, Denis and Rebecca Ott. 1983. Diccionario Ignaciano con Apuntes Gramaticales. Cochabamba: Instituto Linguistico de Verano (ILV).

Parker, Steve. 1995. Datos de la lengua Iñapari. Instituto Lingüístico de Verano (ILV). Pucallpa: Peru.

Payne, David. 1991. A classification of Maipuran (Arawakan) languages based on shared lexical retentions. In: Desmond Derbyshire and Geoffrey K. Pullum (eds.) Handbook of Amazonian Languages. Vol. 3, 355-499. Berlin: Mouton de Gruyter. 
Rose, Françoise. 2015. Mojeño Trinitario. In: Mily Crevels and Pieter Muysken (eds.) Lenguas de Bolivia, Vol. 3. Oriente. La Paz: Plural Editores.

Rowan, Orlando. 2008. Dicionário Paresi-Português. Cuiabá: Sociedade Internacional de Lingüística.

Taylor, Douglas. 1956. Island Carib II: Word-classes, affixes, nouns and verbs. International Journal of American Linguistics 22(1). 1-44.

Taylor, Douglas. 1957. Marriage, Descent and Affinity in Two Arawakan Tribes. International Journal of American Linguistics 23(4). 284290.

Taylor, Douglas. 1961. Some remarks on teknonymy in Arawakan. International Journal of American Linguistics 27(1). 76-80.

WLP 2000. Scholar's Dictionary and Grammar of the Wapishana Language. Wapishana Language Project. Porto Velho: Summer Institute of Linguistics. 